\title{
THERMOPHILIC CAMPYLOBACTER SPP. IN POULTRY MEAT PRODUCTION
}

\author{
Jelena Petrović ${ }^{1 *}$, Igor Stojanov ${ }^{1}$, Vera Gusman², Jelena Lekić \\ Radomir Ratajac ${ }^{1}$, Snežana Medić ${ }^{3}$
}

${ }^{1}$ Scientific Veterinary Institute "Novi Sad”, Novi Sad, Republic of Serbia

${ }^{2}$ Institute for Public Health of Vojvodina, Novi Sad, Republic of Serbia

${ }^{3}$ Institute for Public Health of Vojvodina, Faculty of Medicine,

University of Novi Sad, Republic of Serbia

\section{Abstract}

Thermophilic Campylobacter spp. are the leading cause of zoonotic enteric disease in Europe and USA. In Serbia, it has an upward trend in human population. The disease is usually indirectly transmitted to humans through the consumption of food contaminated by the faeces of infected animals. The aim of this paper was to analyze data on the prevalence of Campylobacter spp. in poultry meat production chain and the risk for the development of the disease in humans. The Campylobacter jejuni/coli was identified at farm level in $73.3 \%$ of poultry, $66.6 \%$ calves and $58.3 \%$ pig samples of already ill or suspected cases. Clinical manifestation of the disease in birds can be expected if an additional immunosuppressive factor is present. Artificial infection of healthy chickens with $6.77 \log$ cfu C. jejuni per chicken on day $21^{\text {st }}$ of life leads to $5.26 \log \mathrm{cfu} / \mathrm{g}$ faeces after only five days with a tendency to decrease during the next 18 days. Although chilling and freezing may significantly reduce Campylobacter contamination of carcasses, it cannot completely eliminate the initial contamination. According to our experimental results the prevalence of Campylobacter contaminated chickens from positive flock appears to drop from 100\% live birds (with $3.02 \mathrm{log}$ $\mathrm{cfu} / \mathrm{g}$ faeces) to $50 \%$ of chicken carcasses. Contamination of the carcasses depends on initial contamination of live birds, good hygiene practices and good manufacturing practices. Therefore, high variability in contamination of carcasses can be considered; prevalence range from 11.43 to $90.00 \%$ of carcases was established in various slaughterhouses. At retail, Campylobac-

${ }^{1 *}$ Corresponding author: jelena@niv.ns.ac.rs 
ter was detected in $18.8 \%$ poultry meat samples and $10.0 \%$ samples of other meat types. Campylobacter is frequently found in the entire production chain of poultry meat and represents high risk for consumers' health.

Key words: Campylobacter, farm, slaughterhouse, retail

\section{TERMOFILNE CAMPYLOBACTER VRSTE U LANCU PROIZVODNJE PILEĆEG MESA}

\section{Jelena Petrović ${ }^{1}$, Igor Stojanov ${ }^{1}$ Vera Gusman², Jelena Lekić Radomir Ratajac ${ }^{1}$, Snežana Medić ${ }^{3}$}

\footnotetext{
${ }^{1}$ Naučni institut za veterinarstvo "Novi Sad”, Novi Sad, Republika Srbija

${ }^{2}$ Institut za javno zdravlje Vojvodine, Novi Sad, Republika Srbija

${ }^{3}$ Institut za javno zdravlje Vojvodine, Medicinski fakultet, Univerzitet u Novom Sadu, Republika Srbija
}

\section{Kratak sadržaj}

Termofilne Campylobacter vrste su jedan od vodećih uzročnika alimentarnih oboljenja u Evropi i USA. U Srbiji postoji rastući trend incidence u humanoj populaciji. Oboljenje se prenosi na čoveka putem hrane koje je kontaminirana fecesom inficiranih životinja. Cilj rada je analiziranje raširenosti Campylobacter spp. u lancu proizvodnje mesa živine i utvrđivanje značaja rizika za zdravlje ljudi. Campylobacter jejuni/coli je identifikovan na nivou farme u 73.3\% uzoraka poreklom od živine, 66.6\% teladi i 58.3\% svinja. Uzorci u ovom istraživanju su poticali od bolesnih ili sumnjivih životinja. Klinička manifestacija oboljenja kod živine se očekuje samo u slučaju prisustva dodatnih, imunosupresivnih faktora. Veštačkom infekcijom zdravih brojlera sa $6.77 \log \mathrm{cfu} C$. jejuni 21. dana života, već nakon pet dana dolazi do izlučivanja $5.26 \mathrm{log} \mathrm{cfu} / \mathrm{g}$ fecesa sa tendencijom opadanja tokom narednih 18 dana. Iako hlađenje i zmrzavanje mogu značajno redukovati kontaminaciju živinskih trupova, nije moguće u potpunosti eliminisati početnu kontaminaciju. Prema našim eksperimentalnim podacima prevalenca Campylobacter kod veštački inficiranih pilića opada sa $100 \%$ živih jedinki (3.02 log cfu/g fecesa) na 50\% klanično obrađenih trupova. Kontaminacija trupova zavisi od početne infekcije živih jedinki i dobre higijenske i dobre proizvodne prakse primenjene u klanici. Stoga nije neobično da postoji visoka varijabilnost u kontaminaciji trupova 
poreklom iz različitih klanica, od 11.43 do $90.00 \%$. U prometu prisustvo Campylobacter je detektovano kod $18.8 \%$ uzorka živinskom mesa i $10.0 \%$ uzorka ostalih vrsta mesa. Campylobacter ima visoku prevalencu u celom lancu proizvodnje živinskog mesa od farme, preko klanice pa sve do mesa u prometu i predstavlja značajan rizik za zdravlje potrošača.

Ključne reči: Campylobacter, farma, klanica, promet

\section{INTRODUCTION}

Campylobacter spp. are microaerophilic, Gram-negative, curved and motile rods, which commonly cannot grow below $30^{\circ} \mathrm{C}$; however, some low metabolic activity is detectable at $40^{\circ} \mathrm{C}$ (EFSA, 2010). The most important foodborne Campylobacter species are thermophilic C. jejuni and C. coli. C. jejuni can be found in the intestines of a range of wild and domestic animals, especially birds. Its prevalence in birds could be attributed to the optimal growth temperature being $42^{\circ} \mathrm{C}$. C. coli can often be identified in the intestines of pigs. In the environment, the organism is isolated from the water, dust, soil, air and also in fish and vegetables (EFSA, 2010). Virulence factors of Campylobacter include motility, chemotaxis, adherence and invasion (Bolton 2015).

Thermophilic non-foodborne Campylobacter species are common causative agents of abortions in sheep and cattle and, occasionally, in other animal species. Thermophilic foodborne species can cause diarrhoea in animals and hepatitis in birds. Campylobacter jejuni/coli often colonize the alimentary tract of poultry and other domestic livestock, yet without development of diseases symptoms. The organisms can commonly be found in the caecum, colon and cloaca, colonizing the crypt and villus region, and are present in the mucus but not in the epithelium. Mucus is the environment that provides optimal oxygen level and improved motility of the bacteria (Mead, 2002). Campylobacter jejuni/coli are much more frequently detected in the caecum and rectum $(70.0 \%)$ than in the reproductive system (uterus and magnum) (6.7\%) of poultry (Stojanov et al., 2008).

\section{CAMPYLOBACTER SPP. IN POULTRY FARMING}

Campylobacter is present in farm surrounding environment, including the soil, water sources, dust, building surfaces, and the air (Ellis-Iversen et al., 2012). Major contamination sources include the environment, domestic and wild animals, water, partial depopulation (thinning) and carry over from 
previous flocks (Barrios et al., 2006; Newell et al., 2011). The prevalence of Campylobacter positive flocks in Europe greatly differs between the countries and ranges between 5 and $90 \%$ depending on the geographic location, climatic differences, biosecurity measures as well as different research methodologies (Berndtson et al., 1996a,b).

If Campylobacter is introduced into the flock at an early phase of breeding, the colonization will most likely persist in all birds until slaughter, and the flock prevalence can reach even $100 \%$. Campylobacter infection spreads within the flock via bird-to-bird transmission route. Such a rapid spread is a result of high expression level (8-9 log cfu/g faeces), coprophagia as well as contamination of drinking water and feeders (Thibodeau et al., 2015). The spread of Campylobacter is mediated also by the presence of flies, mice, and farm workers as the mechanical transmission vectors. Low flock prevalence of Campylobacter indicates recent colonization (Evans and Sayers, 2000).

Colonization occurs most commonly in birds at the age of 2-4 (van Gerwe et al., 2009). Despite extensive colonization, clinical symptoms in poultry are rare and unspecific and include watery diarrhoea often in the absence of pathoanatomical changes in the jejunal mucosa and the caecum. The intestinal bloating and distension consequent to the accumulation of watery and mucous contents are also diagnosed (Evans and Sayers, 2000). Macroscopic necrotic changes are visible in the liver of poultry (Lemos et al., 2015). Diarrhoea commonly occurs some 6 hours post infection, and can persist for up to 10 days. Clinical signs are greatly determined by the amount and virulence of the individual strain of $C$. jejuni, stress factors and immunosuppression (Evans and Sayers, 2000). Our research revealed that clinically manifest campylobacteriosis occurred in experimentally infected chickens with both $C$. jejuni and Salmonella Enteritidis or C. jejuni with simultaneous administration of live D78 Gumboro vaccine. Major clinical symptom was watery diarrhoea that varied in intensity between birds. Diarrhoea did not occur in chickens infected with only C. jejuni or only Salmonella Enteritidis. The administration of immunosuppressive agents induced clinically manifested signs associated with the occurrence of red or yellow spots on the liver (Stojanov et al., 2008). Immunosuppressive agents such as dexamethasone, ochratoxin A and secondary bacterial infections also promote clinical signs of campylobacteriosis (Stojanov et al., 2011).

In chicken categories older than three weeks, the infection with $C$. jejuni strains results in intestinal colonization, yet not in the clinical manifestations of the disease (Petrović et al., 2008; Petrović et al., 2012). Chickens inoculated with $C$. jejuni at the beginning of the fourth week of age ( $21^{\text {st }}$ day of life) had 
an average C. jejuni count of $5.26 \mathrm{log} \mathrm{cfu} / \mathrm{g}$ on day 5 post-infection. A trend of $C$. jejuni count is displayed in Figure 1. after an initial growing tendency during first five days after infection, a continuous decrease has been observed during the period between day 11 and day 18 post-infection (from 4.97 to 3.02 $\log \mathrm{cfu} / \mathrm{g}$ ) followed by an increase in C. jejuni count to $4.95 \log \mathrm{cfu} / \mathrm{g}$ (day 28 post-infection).

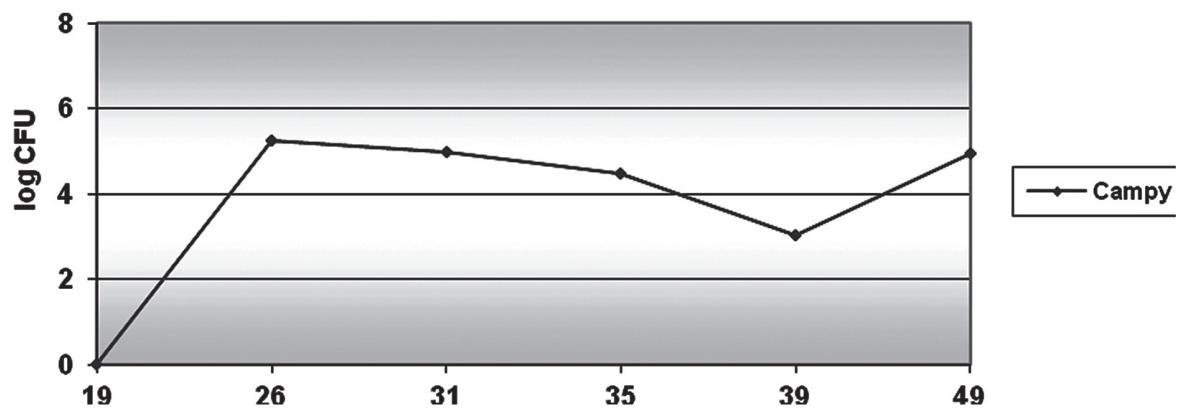

Figure 1. Average total count of C. jejuni in infected chickens (Petrović et al., 2012)

Surrounding environment including air distribution in the facility, open doors and windows, improper footwear, two or more workers in charge for the facility, presence of rodents and insects, two or more housing units at the farm, vicinity of farms with other domestic livestock, feed storage outside the facility and on-farm storage of broiler carcasses before distribution can represent important risk factors for the development of infection in broilers. Feedstuffs are not a suitable medium for multiplication of Campylobacter organisms, so drinking water remains far more important risk factor (Sibanda et al., 2018).

In cases when there are several units for flock accommodation at the same farm, Campylobacter infection can be identified in some flocks, while other ones remain Campylobacter-free. The susceptibility to colonization with Campylobacter strains increases with the age of the birds and flock size (Berndtson, 1996b). Gibbens et al. (2001) reported reduction of facility contamination by over $50 \%$ after application of relevant disinfection protocols. Poultry transportation equipment and cages are also potential sources of Campylobacter. Transportation negatively affects the poultry population and increases contamination due to the exposure to other birds' faeces (which is more likely to be watery due to stress conditions) (Dogan et al., 2019). The transmission of Campylobacter spp. across the farm occurs rapidly and the infection spreads flock-wide within only few days, which supports the theory that if the infection is present, every single bird in the flock is affected (Berndtson 1996b). 


\section{CAMPYLOBACTER SPP. IN SLAUGHTERHOUSES}

Dominant route of Campylobacter contamination of poultry carcasses in a slaughterhouse is the rupture of intestines and consequent leakage and spread of the faeces. Another source is improper hygiene practice (cleaning and disinfection) in the facility (Hansson et al., 2005; Peryat et al., 2008). Carcass contamination is substantially influenced by biological properties of Campylobacter. Though microaerophilic and thus difficult to grow under common conditions in the food production chain, Campylobacter survives the acidative and oxidative stress and modified atmospheric packaging. This strongly indicates its high capability of adapting to unfavourable environmental conditions and surviving food processing procedures. Biological properties enabling the adaptability of this organism to stress include antioxidant defence, ability to enter to viable but not countable state (VBNC state), selection of virulent strains, antimicrobial resistance genes transfer and wide genetic variability (Meredith et al., 2014; Bolton 2015; Gomes et al., 2018).

Campylobacter contamination at slaughterhouse is closely related with the colonization status of broilers during rearing. Colonized chickens carry large amounts of Campylobacter in the caecum (5-8 log cfu) and intestines. Such chickens shed Campylobacter in the faeces during transportation and spread it into the environment (Dogan et al., 2019). Flock prevalence rate and Campylobacter concentration in the caecum along with the hygienic standards applied during processing strongly influence the amount of the pathogens in final poultry products and hence the exposure of the consumers to thermophilic Campylobacter species from poultry meat.

Major points of potential contamination in the slaughterhouse include picking, evisceration and some chilling processes. Leaking of faecal content during picking and evisceration process leads to carcass contamination; even very small amounts of the faeces can significantly elevate the Campylobacter counts on the carcasses. Immersion chilling with chlorinated water reduces contamination but without chlorine the contamination increases (Guerin et al., 2010; Dogan et al., 2019).

Contamination of carcasses could be reduced by scalding, washing and cold storage. During scalding, a part of Campylobacter organisms is washed out of the carcass surface. However, scalding water easily becomes contaminated with faecal contents and dust, thus causing recontamination of the carcass with certain amount of pathogens if scalding technology is not properly applied. The temperature of scalding water does not significantly influence the Campylobacter counts. Washing substantially reduces the concentration of Campylobacter 
(90\%), while airflow-chilling reduces Campylobacter counts depending on the temperature and humidity (Guerin et al., 2010; Dogan et al., 2019). Campylobacter contamination can be detected on all parts of broiler carcass neck skin, visceral cavity, even the region under the skin. The number of Campylobacter on the carcass commonly ranges around 2-3 log $\mathrm{cfu} / \mathrm{cm}^{2}$. Dry environment as well as the storage at $4^{\circ} \mathrm{C}$ or freezing result in the decrease of Campylobacter counts. Freezing at $18^{\circ} \mathrm{C}$ during 10 and 21 days will reduce the number of Campylobacter for $90 \%$ and $99 \%$, respectively. However, there are reports on Campylobacter isolation from broiler carcasses even after 83 weeks of freezing. Even though current processing procedures reduce the Campylobacter count, the organism can often be found in final products at the range $1-4 \mathrm{log} / \mathrm{cm}^{2}$. Cross-contamination at the slaughterhouse is considered possible yet limited, having in mind low concentration of Campylobacter on cross-contaminated carcasses as related to those originating from poultry that has previously been colonized with Campylobacter. Transmission of Campylobacter from cross-contaminated meat to the final products during processing is very unlikely, as well as the probability for consequent human infection and disease (EFSA, 2010).

The rate of carcass contamination at the slaughterhouse varies among poultry originating from Campylobacter colonized flocks. At certain production stages, the count of Campylobacter on the carcass can increase or decrease, and there are reports about complete elimination of all Campylobacter so the carcasses were free from Campylobacter. Various technological procedures applied at the slaughterhouses can affect cross-contamination and contamination of carcasses of poultry originating from Campylobacter-free flocks (Rosenquist et al., 2003). Slaughtering of flocks with $100 \%$ of infected birds results in $50 \%$ contaminated carcasses (Petrović et al., 2008). The prevalence of contamination significantly varies between individual slaughterhouses (Table 1).

Table 1. Occurrence of thermophilic Campylobacter spp. in poultry samples (Petrović et al., 2008)

\begin{tabular}{cccccccc}
\hline $\begin{array}{c}\text { Occurrence of } \\
\begin{array}{c}\text { Campylobacter } \\
\text { spp. (\%) }\end{array}\end{array}$ & $\mathrm{A}$ & $\mathrm{B}$ & $\mathrm{C}$ & $\mathrm{D}$ & $\mathrm{E}$ & $\mathrm{F}$ & $\mathrm{G}$ \\
\hline liver & 40.00 & 5.00 & 8.56 & 6.00 & 34.28 & 2.86 & 5.71 \\
carcasses & 90.00 & 14.28 & 51.43 & 20.01 & 68.57 & 11.43 & 31.43 \\
\hline
\end{tabular}




\section{CAMPYLOBACTER SPP. AT RETAIL}

The presence of thermophilic Campylobacter in meat on the market varies depending on the product type the highest risk is associated with whole poultry carcass, somewhat lower prevalence is evident in skin-off whole pieces. Minced meat is considered low-risk product because of beneficial effects of spices and oxidative stress as well as the range of poultry meat products (such as sausages, etc.) (Simone et al., 2017). In Serbian market, poultry meat is available as chilled $\left(+4^{\circ} \mathrm{C}\right)$ or frozen $\left(-20^{\circ} \mathrm{C}\right)$ product. Chilling does not significantly affect the survival of Campylobacter, whereas freezing reduces contamination (Reiersen et al., 2001). Campylobacter has been identified in 18.8\% poultry meat samples and $10.0 \%$ of samples of other meat samples in a retail chain (Trajković et al., 2007).

Campylobacteriosis is the most commonly reported gastrointestinal human disease in the EU/EEA (EFSA and ECDC, 2018). Most common sources of human disease are undercooked or improperly heat treated meat, unpasteurized milk, dairy products and contaminated water. Some half of all cases of human campylobacteriosis in the USA is considered to be associated with consumption of poultry meat. After the incident with dioxin contamination in Belgium in 1999, poultry meat and relevant products were withdrawn from the market, which resulted in a $40 \%$ drop of the incidence of human campylobacteriosis. Grilling meat is at particular risk of infection development due to easy transmission of bacteria from raw meat to the hands and thus to other food while handling (Jorgensen, 2002). The risk of campylobacteriosis associated with consumption of pork and beef meat is considered relatively law; however, undertreated offal products still pose substantial risk. Important sources of human campylobacteriosis include drinking water and fresh products contaminated with campylobacteria from irrigation water. The presence of Campylobacter spp. in drinking and irrigation water is due to faecal contamination (EFSA, 2010).

\section{CONTROL MEASURES}

Qualitative risk analysis revealed that decrease in flock contamination level by $3 \log$ cfu does not lead to significant decrease in the number of contaminated carcasses processed at the slaughterhouse; however, the Campylobacter count on the carcasses was significantly reduced (Reiersen et al., 2001). Quantitative risk analysis proved that even law reduction of Campylobacter spp. count in poultry faeces $(2 \mathrm{log})$ decreases the incidence of human infection 30 times (Rosenquist et al., 2018) suggesting that control, that is, reduction of 
Campylobacter in poultry faeces at the farms is a crucial measure for the prevention of human infections. Quantitative risk analysis also revealed a linear relationship between flock prevalence and number of contaminated carcasses after processing in the slaughterhouse, thus, compliance to strict hygienic barriers is the only effective approach to reducing the flock prevalence of Campylobacter (Reiersen et al., 2001).

Reduction of Campylobacter count on carcass surface can be accomplished by increasing scalding temperature, improving evisceration techniques, usage of large amounts of water across the entire production line, increasing the airflow at chilling and introducing relevant disinfection practices. Prevention of cross-contamination during transport of live chickens is of vital importance, also. However, all the aforementioned measures are of lesser influence on the decrease in rate of human infections as compared to the reduction of the incidence of Campylobacter in the flock.

\section{CONCLUSION}

Campylobacteriosis is one of the most important foodborne diseases mostly associated with consumption of contaminated poultry meat. In order to reduce the number of disease episodes, relevant measures should be applied across the entire poultry meat production chain and especially at poultry farms. Strict compliance with relevant biosecurity measures prevents the introduction of the pathogen into the production process at the farm. Adequate hygiene and sanitation practices in the slaughterhouses can prevent cross-contamination and decrease the contamination level. Ensuring of cold chain supply of poultry meat also contributes to an effective disease control. Successful protection of human population from alimentary diseases is closely associated with a range of preventive activities across the entire meat production chain and responsibility of each individual participant of this production chain.

\section{ACKNOWLEDGEMENT}

This work was supported by the Ministry of Science and Technological Development of the Republic of Serbia, grants TR 31084.

\section{Author's contributions:}

JP and RR made contributions to conception and design of the article, involved in data collection and drafting the manuscript. IS contributed with data about Campylobacter at farm level and manifestation of clinical campylobac- 
teriosis. JP contributed with data about Campylobacter dynamics in artificially infected poultry and data about slaughterhouse prevalence. VG and JL contributed with data about Campylobacter prevalence at retail level. SM revised the manuscript critically and together with JP prepared the final draft of the manuscript. All authors read and approved the final manuscript.

\section{Competing interest}

Authors declared no conflict of interests regarding the present paper.

\section{REFERENCES}

1. Barrios P.R., Reuersen J., Lowman R., Bisaillon J.R., Michel P., Fridriksdottir V., Gunnarsson E., Stern N., McEwen O.S., Martin W. 2006. Risk factors for Campylobacter spp. colonization in broiler flocks in Iceland. Preventive Veterinary Medicine, 74, 4, 264-278.

2. Berndtson E., Danielsson-Tham M., Engvall A. 1996a. Campylobacter incidence on a chicken farm and the spread of Campylobacter during the slaughter process. International Journal of Food Microbiology 32, 35-47.

3. Berndtson E., Emanuelson U., Engvall A., Danielsson-Tham M. 1996b. A 1-year epidemiological study of campylobacter in 18 Swedish farms. Preventive Veterinary Medicine, 26, 167-185.

4. Bolton D.J. 2015. Campylobacter virulence and survival factors. Food Microbiology 48, 99-108.

5. Dogan O., Clarke J., Mattos F., Wang B. 2019. A quantitative microbial risk assessment model of Campylobacter in broiler chickens: Evaluating processing interventions. Food Control, 100, 97-110.

6. Guerin M., Sir C., Sargeant J., Waddell L., Oconnor A., Wils R. 2010. The change in prevalence of Campylobacter on chicken carcasses during processing: A systematic review. Poultry Science, 89, 1070-1084.

7. EFSA, European Food Safety Authority. 2010. Scientific Opinion on Quantification of the risk posed by broiler meat to human campylobacteriosis in 2010. EFSA Journal 1437, 1, 1-89.

8. EFSA and ECDC, European Food Safety Authority and European Centre for Disease Prevention and Control. 2018. The European Union summary report on trends and sources of Zoonoses, zoometric agents and food borne outbreaks in 2017, EFSA Journal, 16, 12, 1-262.

9. Ellis-Iversen J., Ridley A., Morris V., Sowa A., Harris J., Atterbury R., Sparks N., Allen V. 2012. Persistent environmental reservoirs on farms as risk factors for Campylobacter in commercial poultry. Epidemiology and Infection, 140, 916-924. 
10. Evans S.J., Sayers A.R. 2000. A longitudinal study of Campylobacter infection of broiler flocks in Great Britain. Preventive Veterinary Medicine, 46, 209-223.

11. Gibbens J., Pascoe S., Evans S., Davies R., Sayers A. 2001. A trial of biosecurity as a means to control Campylobacter infection of broiler chickens. Preventive Veterinary Medicine, 48, 2, 85-99.

12. Gomes C.N., Passaglia J., Vilela F.P., Pereira da Silva F.M.H.S., Duque S.S., Falcão J.P. 2018. High survival rates of Campylobacter coli under different stress conditions suggest that more rigorous food control measures might be needed in Brazil. Food Microbiology, 73, 327-333.

13. Hansson I., Ederoth M., Andersson L., Vågsholm I., Olsson E. 2005. Transmission of Campylobacter spp. to chickens during transport to slaughter. Journal of Applied Microbiology, 99, 5, 1149-1157.

14. Jorgensen F., Bailey R., Williams S., Henderson P., Wareing D., Bolton F., Frost A., Ward L., Humphrey T. 2002. Prevalence and numbers of Salmonella and Campylobacter spp. on raw, whole chickens in relation to sampling methods. International Journal of Food Microbiology, 76, 154-164.

15. Lemos A., Morais L., da Conceição Fontes M., Pires I., Vieira-Pinto M. 2015. Campylobacter spp. isolation from infected poultry livers with and without necrotic lesions. Food Control, 50, 236-242.

16. Mead G. 2002. Factors affecting intestinal colonisation of poultry by Campylobacter and role of microflora in control. World's Poultry Science Journal, 58, 169-178.

17. Meredith H., Valdramidis V., Rotabakk B.T., Sivertsvik M., McDowell D., Bolton D.J. 2014. Effect of different modified atmospheric packaging S (MAP) gaseous combinations on Campylobacter and the shelf-life of chilled poultry fillets. Food Microbiology, 44, 196-203.

18. Newell K.T., Elvers D., Dopfer I., Hansson P., Jones S., James J., Gittins N.J., Stern R., Davies I., Conerton D., Pearson D., Salvat V.M. 2011. Biosecurity based interventions and strategies to reduce Campylobacter spp. on poultry farms. Applied Environmental Microbiology, 77, 8605-8614.

19. Petrović J., Milanov D., Ratajac R. 2008. Savremeni trendovi u bezbednosti hrane: Rezistencija zoonotskih patogena prema antimikrobnim lekovima. Veterinarski glasnik, 62, 5-6, 257-406.

20. Petrović J., Stojanov I., Milanov D., Velhner M., Stojanović D. 2012. Four steps to risk assessment of Campylobacter contamination in broiler production in Serbia. In Proceedings, 6th Central European Congress on Food Institute for Food Technology, Novi Sad, Serbia 23-26.05.2012, 602-606.

21. Peyrat M.B., Soumet C., Maris P., Sanders P. 2008. Recovery of Campylobacter jejuni from surfaces of poultry slaughterhouses after cleaning and 
disinfection procedures: analysis of a potential source of carcass contamination. International Journal of Food Microbiology, 124, 2, 188-194.

22. Reiersen H., Briem H., Hardardottir E., Gunnarsson F., Georgsson K.G. 2001. Human campylobacteriosis epidemic in Iceland 1998-2000 and effect of interventions aimed at poultry and humans. International Journal of Medical Microbiology, 291, 31,153.

23. Rosenquist H., Nielsen N.L., Sommer H.M., Nørrung B., Christensen B.B.: 2003. Quantitative risk assessment of human campylobacteriosis associated with thermophilic Campylobacter species in chickens. International Journal of Food Microbiology, 83, 87-103.

24. Sibanda N., McKenna A., Richmond A., Ricke S.C., Callaway T., Stratakos A.C., Gundogdu O., Corcionvochi N. 2018. A Review of the Effect Management Practices on Campylobacter Prevalence in Poultry Farms. Frontiers in Microbiology doi: 10.3389/fmicb.2018.02002.

25. Simone S., Soncini G., Ziino G., Panebianco A., Giaccone V. 2017. Prevalence and quantification of thermophilic Campylobacter spp. in Italian retail poultry meat: Analysis of influencing factors. Food Microbiology, 62, 232-238.

26. Stojanov I., Milić N., Ašanin R., Vidić B., Grgić Ž., Prica N. 2008. Effects of some immunosuppressive factors on campylobacteriosis outbreaks in poultry. Acta Veterinaria 58, 2-3,167-177.

27. Stojanov I., Stojanović D., Milić N., Živkov-Baloš M., Kapetanov M. 2011. Influence of Salmonella Infection in Chickens on the Outcome of Campylobacteriosis in Experimental Conditions. Acta Veterinaria 61, 1, 57-65.

28. Thibodeau A., Fravalo P., Yergeau E., Arsenault J., Lahaye L., Letellier A. 2015. Chicken caecal microbiome modifications induced by Campylobacter jejuni colonization and by a non-antibiotic feed additive PLOS One, 10, Article 0131978. https://journals.plos.org/plosone/article?id=10.1371/ journal.pone.0131978

29. Trajković-Pavlović L., Popović B., Novaković B., Gusman-Pasterko V., Jevtić M., Mirilov J. 2007. Occurrence of Campylobacter, Salmonella, Yersinia enterocolitica and Listeria monocytogenes in some retail food products in Novi Sad. Central European Journal of Public Health 15, 4, 167-171.

30. van Gerwe T., Miflin J.K., Templeton J.M., Bouma A., Wagenaar J.A., Jacobs-Reitsma W.F., Stegeman A., Klinkenberg D. 2009. Quantifying transmission of Campylobacter jejuni in commercial broiler flocks. Applied Environmental Microbiology, 75, 625-628. 